\author{
Robert SZMYTKIE \\ Dr, Zakład Geografii Społeczno-Ekonomicznej, Instytut Geografii i Rozwoju Regionalnego, Uniwersytet Wrocławski \\ robert.szmytkie@uwr.edu.pl
}

\title{
DEPOPULACJA ZESPOŁÓW MIEJSKICH W SUDECKIEJ CZĘŚCI DOLNEGO ŚLĄSKA
}

\begin{abstract}
Abstrakt: Głównym celem opracowania jest analiza zmian ludnościowych, jakie miały miejsce w aglomeracjach jeleniogórskiej i wałbrzyskiej w latach 1995-2014. Sytuację demograficzną Jeleniej Góry i Wałbrzycha pogorszyły niekorzystne zmiany społeczno-gospodarcze i administracyjne w latach 90. XX w. Ubytek liczby ludności w tych miastach nie jest rekompensowany przez procesy suburbanizacji w ich otoczeniu. Dotyczy to w szczególności aglomeracji wałbrzyskiej, gdzie rozwój suburbanizacji utrudnia słabość bazy ekonomicznej tutejszych ośrodków miejskich oraz niekorzystny wizerunek Wałbrzycha i całego regionu wałbrzyskiego. Negatywny wpływ na sytuację demograficzną obu zespołów miejskich ma także oddziaływanie niedalekiego Wrocławia.

Słowa kluczowe: depopulacja, zespół miejski, suburbanizacja, Jelenia Góra, Wałbrzych.
\end{abstract}

\section{DEPOPULATION OF URBAN AGGLOMERATIONS IN THE SOUTH PART OF THE LOWER SILESIA}

Abstract: The main object of this paper was the analysis of population changes which took place in the years 1995-2014 in the Jelenia Góra and Wałbrzych agglomerations. Current poor demographic situation of Jelenia Góra and Wałbrzych is caused by the negative economic, social and administrative changes, which occurred in the last decade of the 20th century. Depopulation of the both cities was not compensated by suburbanization of their hinterlands. This problem concerned the Wałbrzych agglomeration in particular. Low dynamics of suburbanization was caused there by a weakness of the economic base of local urban centres and by a negative image of the Wałbrzych city and the entire Wałbrzych Basin. A proximity of Wrocław city has also negatively influenced the demographic situation of both discussed agglomerations.

Keywords: depopulation, urban agglomeration, suburbanization, Jelenia Góra, Wałbrzych.

\section{WPROWADZENIE}

Kluczową rolę w sieci osadniczej województwa dolnośląskiego odgrywają zespoły miejskie. Do najważniejszych aglomeracji $\mathrm{w}$ tym regionie należą monocentryczna aglomeracja wrocławska (często określana też jako Wrocławski Obszar Metropolitalny - por. Markowski, Marszał 2006, Koncepcja... 2009, Smętkowski, Jałowiecki, Gorzelak 2009) i trzy zespoły miejskie o znaczeniu regionalnym: policentryczna aglomeracja legnicko-głogowska oraz monocentryczne aglomeracje jeleniogórska i wałbrzyska. Wszystkie one znacznie różnią się od siebie pod względem zachodzących zmian demograficznych (Szmytkie 2015a). W aglomeracji wrocławskiej występuje wzrost liczby mieszkańców, co wynika z napływu ludności do Wrocławia i gwałtownego rozwoju jego strefy podmiejskiej (Maleszka, Szmytkie 2009). W aglomeracji legnicko-głogowskiej ubytek liczby ludności w głównych miastach zespołu (Legnica, Lubin, Głogów) rekompensowany jest przez napływ ludności do ich stref podmiejskich (Mayer, Szmytkie 2014). W znacznie mniej korzystnej sytuacji ludnościowej znajdują się zaś zespoły miejskie Jeleniej Góry i Wałbrzycha. Depopulacja największych miast tej części województwa nakłada się bowiem na niekorzystne zmiany demograficzne występujące na obszarach wiejskich, które w przypadku wsi sudeckich obserwowane były właściwie przez cały okres powojenny (Miszewska 1999, Zagożdżon 1990, Ciok 1995, Cieślak, red. 1999, Górecka, Kozieł, Tomczak 2009).

Głównym celem opracowania jest analiza zmian ludnościowych, jakie miały miejsce w aglomeracjach jeleniogórskiej i wałbrzyskiej w latach 1995-2014. Zakres przestrzenny obu zespołów miejskich został wyznaczony w oparciu o istniejące powiązania funkcjonalne (dojazdy do pracy w Jeleniej Górze i Wałbrzychu w 2011 r. $^{1}$ ). Na tej podstawie w skład aglomeracji jeleniogórskiej zaliczono: Jelenią Górę, gminy powiatu jeleniogórskiego, gminy Lubomierz i Wleń z powiatu lwóweckiego oraz gminy Świerzawa i Wojcieszów z powiatu złotoryjskiego, a do aglomeracji wałbrzyskiej: Wałbrzych, gminy powiatu wałbrzyskiego i miasto 
Świebodzice z powiatu świdnickiego. Tak wyznaczona aglomeracja jeleniogórska zajmuje powierzchnię 1145,1 km² a w 2014 r. liczyła 168,5 tys. mieszkańców (147 osób na $\mathrm{km}^{2}$ ), natomiast aglomeracja wałbrzyska obejmuje 545,4km², w której w 2014 r. było 197,4 tys. mieszkańców (362 osoby na $\mathrm{km}^{2}$ ). W analizie zwrócono uwagę nie tylko na główne tendencje zmian demograficznych i ich skutki przestrzenne, lecz również na czynniki zmian ludnościowych, ich zróżnicowanie przestrzenne oraz przewidywane zmiany liczby ludności w obu zespołach miejskich w najbliższych latach.

\section{ZMIANY LUDNOŚCIOWE W AGLOMERACJACH JELENIOGÓRSKIEJ I WAŁBRZYSKIEJ W LATACH 1995-2014}

W dwudziestoleciu 1995-2014 liczba ludności w Jeleniej Górze zmniejszyła się z 93,5 tys. osób w 1995 r. do 81,4 tys. w 2014 r., czyli o 12,9\% (średnio 634 osoby rocznie). Jeszcze bardziej dotkliwy spadek liczby mieszkańców wystąpił w Wałbrzychu - ze 139,2 tys. osób w 1995 r. do 116,7 tys. w 2014 r., czyli o 16,2\% (średnio 1185 osób rocznie). W obu miastach tempo depopulacji znacznie nasiliło się po 1998 r., czyli po utracie statusu ośrodków wojewódzkich (w Jeleniej Górze ubytek liczby ludności wyniósł 781 osób rocznie, a w Wałbrzychu 1265). O skali depopulacji świadczy fakt, że Jelenia Góra i Wałbrzych należą do najszybciej wyludniających się miast w Polsce - w analizowanym okresie więcej mieszkańców straciły jedynie Łódź, Poznań i większe z miast konurbacji katowickiej (Krzysztofik, Szmytkie 2011, Stryjakiewicz, red. 2014, Szmytkie 2015b) - oraz do najszybciej wyludniających się byłych miast wojewódzkich (Szmytkie 2006). Na ubytek liczby ludności wpłynęła również przebudowa bazy ekonomicznej obu miast w latach 90 . XX w., co związane było $\mathrm{z}$ likwidacją górnictwa węglowego w Zagłębiu Wałbrzyskim (por. Wójcik 2011, Dołzbłasz, Mucha 2015) oraz z zamknięciem największych zakładów przemysłu przetwórczego, jak np. Zakładów Włókien Chemicznych Chemitex-Celwiskoza w Jeleniej Górze.

Jednocześnie depopulacja w obu miastach nie została zrównoważona przez wzrost liczby ludności w ich otoczeniu. Taki dualizm rozwoju demograficznego (depopulacja miasta i wzrost demograficzny w gminach zlokalizowanych $\mathrm{w}$ jego otoczeniu, będący wynikiem procesów suburbanizacji) jest typowy dla większości miast dużych i średnich² (por. Kantor-Pietraga 2014).
W analizowanym 20-leciu liczba ludności w gminach aglomeracji wałbrzyskiej zmniejszyła się o 7,3 tys. osób, czyli o 8,3\% (rys. 1), a w gminach aglomeracji jeleniogórskiej o 4,0 tys. osób, czyli 5,1\% (rys. 2). Warto jednak zauważyć, że w ostatnich latach sytuacja demograficzna gmin podmiejskich Jeleniej Góry i Wałbrzycha znacznie się poprawiła (w niektórych latach odnotowano tu nawet wzrost liczby ludności), co świadczy o zapoczątkowaniu procesów suburbanizacji na ich obszarze (por. Maciejuk 2015).

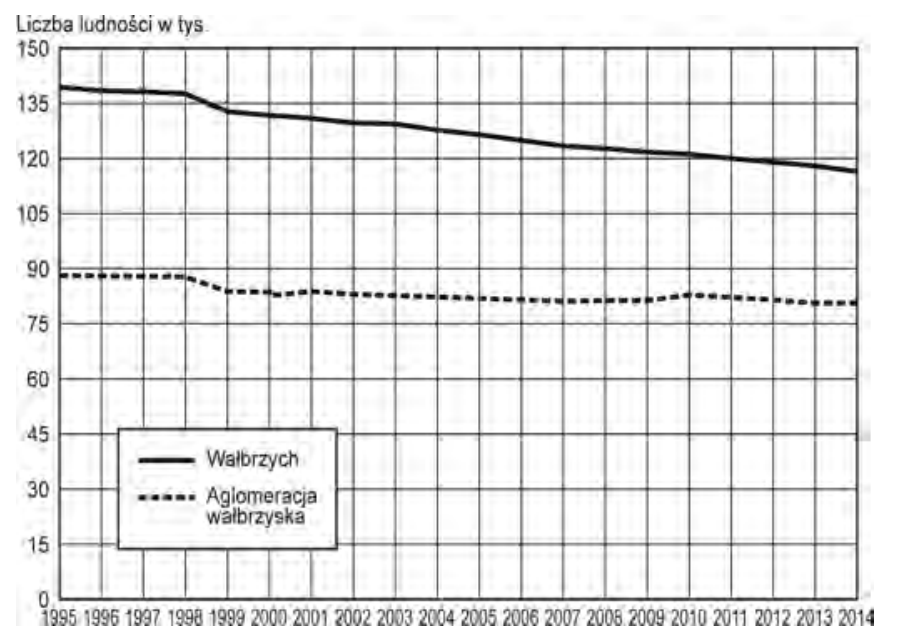

Rys. 1. Zmiany liczby ludności w aglomeracji wałbrzyskiej w latach 1995-2014

Źródło rys. 1-4 i 7-10: opracowanie własne na podstawie Banku Danych Lokalnych GUS

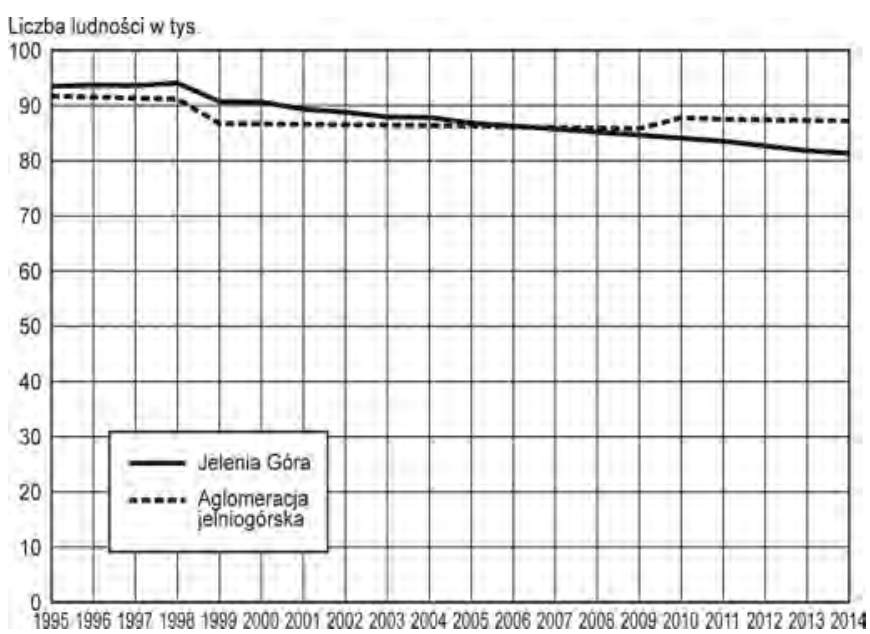

Rys. 2. Zmiany liczby ludności w aglomeracji jeleniogórskiej w latach 1995-2014

O sytuacji demograficznej obu miast i gmin położonych w ich otoczeniu świadczą też czynniki zmian ludnościowych rozpatrywane w nawiązaniu do typologii J. Webba (1963). W analizowanym okresie Jelenia Góra przeszła od typu D (w którym dodatnie saldo 


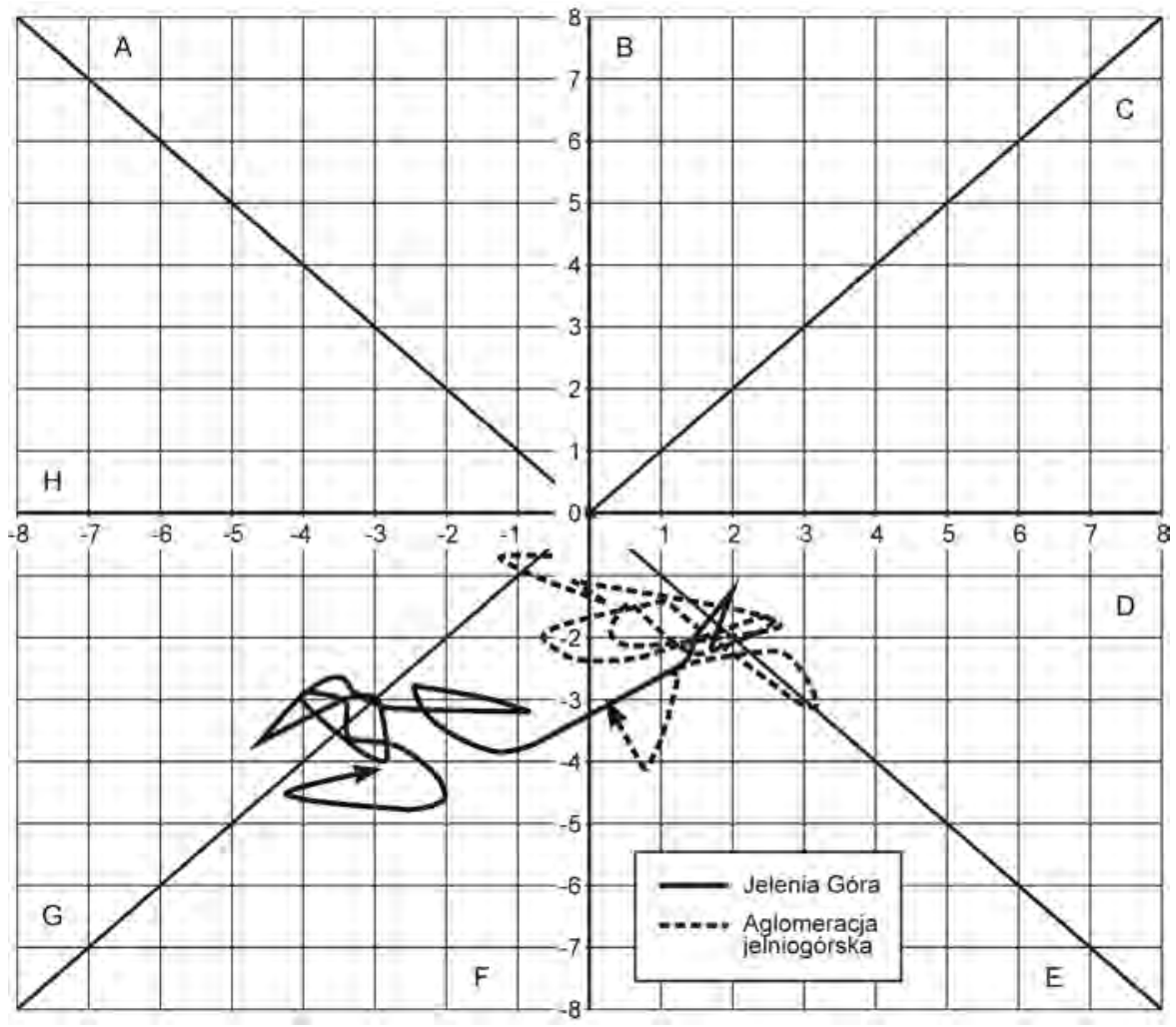

Rys. 3. Czynniki zmian ludnościowych w aglomeracji jeleniogórskiej w latach 1995-2014 (diagram Webba)

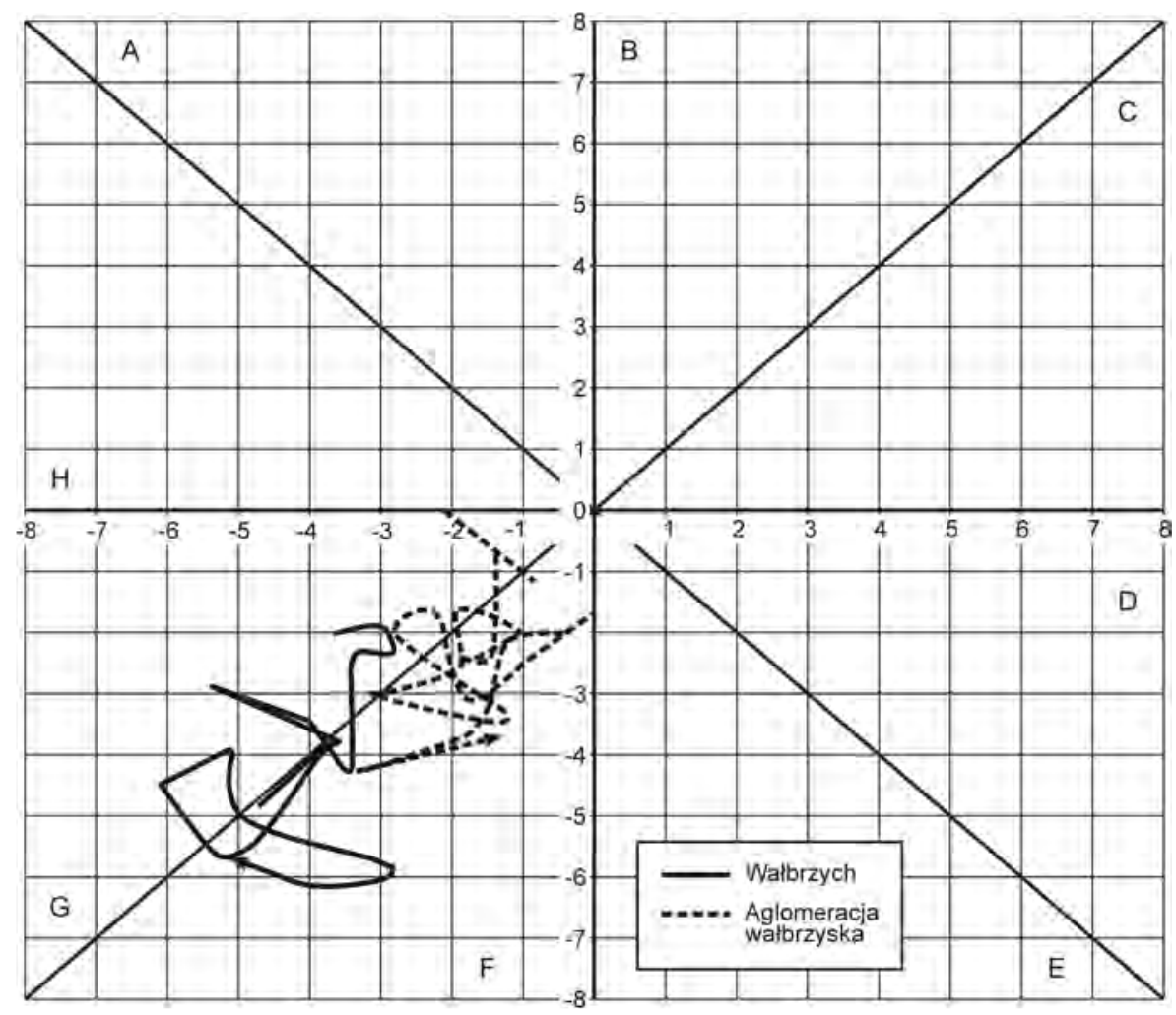

Rys. 4. Czynniki zmian ludnościowych w aglomeracji wałbrzyskiej w latach 1995-2014 (diagram Webba) 
migracji rekompensuje ubytek naturalny), przez typy E, F i G, do typu F (gdzie ubytek naturalny przeważa nad ujemnym saldem migracji). Gminy aglomeracji jeleniogórskiej przeszły z kolei z typu F do typu E (gdzie ubytek naturalny nie jest rekompensowany przez dodatnie saldo migracji), co świadczy o występowaniu procesów suburbanizacji w otoczeniu Jeleniej Góry (rys. 3). W przypadku Wałbrzycha i gmin położonych w jego otoczeniu procesy depopulacji wywołane były zarówno przez ubytek naturalny, jak i ujemne saldo migracji, stąd też $\mathrm{w}$ analizowanym dwudziestoleciu jednostki te koncentrowały się w typach F i G (gdzie ujemne saldo migracji przeważa nad ubytkiem naturalnym) (rys. 4).

Analiza kierunków migracji wewnętrznych z Jeleniej Góry (rys. 5) i Wałbrzycha (rys. 6) w latach 2000-

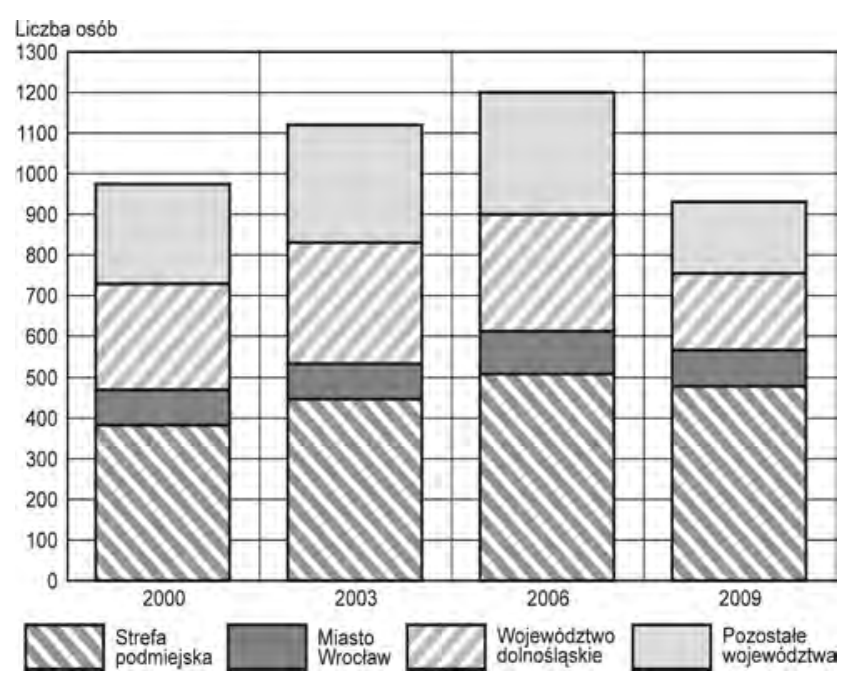

Rys. 5. Wymeldowania z Jeleniej Góry w latach 2000-2009 Źródło: opracowanie własne

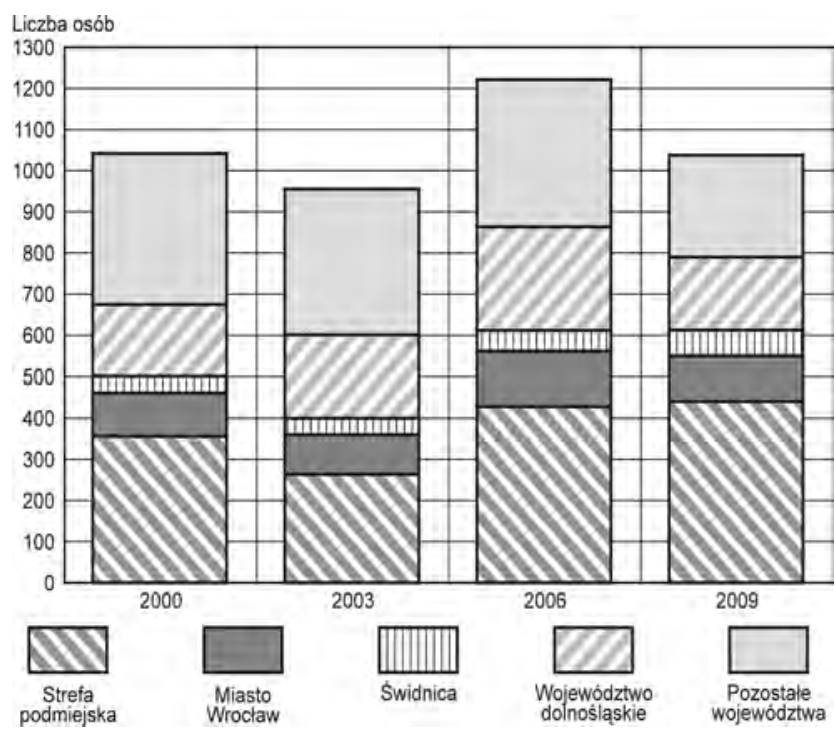

Rys. 6. Wymeldowania z Wałbrzycha w latach 2000-2009 Źródło: opracowanie własne
2009 (por. Śleszyński 2013) wskazuje na nieznaczny udział wymeldowań do gmin położonych w strefach podmiejskich obu miast. W przypadku Jeleniej Góry wzrósł on z 45,7\% w 2000 r. do 53,0\% w 2009 r., natomiast w Wałbrzychu z 34,0\% w 2000 r. do $42,5 \%$ w 2009 r. Wynika to przede wszystkim z bliskości Wrocławia, do którego migrują głównie osoby młode (migracje zarobkowe lub ze względów edukacyjnych), a w Wałbrzychu także z konkurencji pobliskiej Świdnicy. Wymeldowania do Wrocławia w przypadku obu miast stanowią około 10-11\% ogólnej liczby wymeldowań (czyli po ok. 100 osób rocznie), natomiast wymeldowania z Wałbrzycha do Świdnicy wzrosły z 3,7\% w 2000 r. do 5,9\% w 2009 r. Ponadto w Wałbrzychu widoczne jest zjawisko migracji powrotnych, czyli odpływu osób, które przybyły do tego miasta w latach 70 . i 80. XX w. z różnych regionów Polski, co związane było $\mathrm{z}$ podjęciem pracy $\mathrm{w}$ miejscowych kopalniach węgla kamiennego i zakładach przemysłowych. Jest to zjawisko typowe dla ośrodków poprzemysłowych (por. Spórna, Kantor-Pietraga, Krzysztofik 2015/2016).

\section{ZRÓŻNICOWANIE PRZESTRZENNE ZMIAN LUDNOŚCIOWYCH W AGLOMERACJACH JELENIOGÓRSKIEJ I WAŁBRZYSKIEJ W LATACH 1995-2014}

Zmiany ludnościowe w aglomeracjach jeleniogórskiej i wałbrzyskiej, mimo ogólnego trendu depopulacyjnego, cechują się dość znacznym zróżnicowaniem w układzie gmin wchodzących w skład tych zespołów miejskich. Dowodzi to różnorodności procesów demograficznych w ich obrębie. Procesy depopulacji są typowe dla centralnych miast aglomeracji (Jelenia Góra, Wałbrzych) oraz ich miast satelickich, zwłaszcza ośrodków turystycznych (Szklarska Poręba, Karpacz, Jedlina-Zdrój, Szczawno-Zdrój) i poprzemysłowych (Boguszów-Gorce, Głuszyca, Kowary, Mieroszów, Piechowice) (rys. 7). Ubytek liczby mieszkańców w latach 1995-2014 wystąpił także na obszarach wiejskich położonych peryferyjnie względem miast centralnych (wiejskie części gmin Wleń, Głuszyca, Mieroszów). W gminach wiejskich graniczących z Jelenią Górą i Wałbrzychem miał z kolei miejsce wzrost liczby ludności (dotyczy to jednak tylko gmin sąsiadujących z Jelenią Górą, tzn. Jeżowa Sudeckiego, Podgórzyna, Janowic Wielkich) lub ich zaludnienie utrzymało się na podobnym poziomie (gminy Mysłakowice, Stare Bogaczowice, Czarny Bór). 

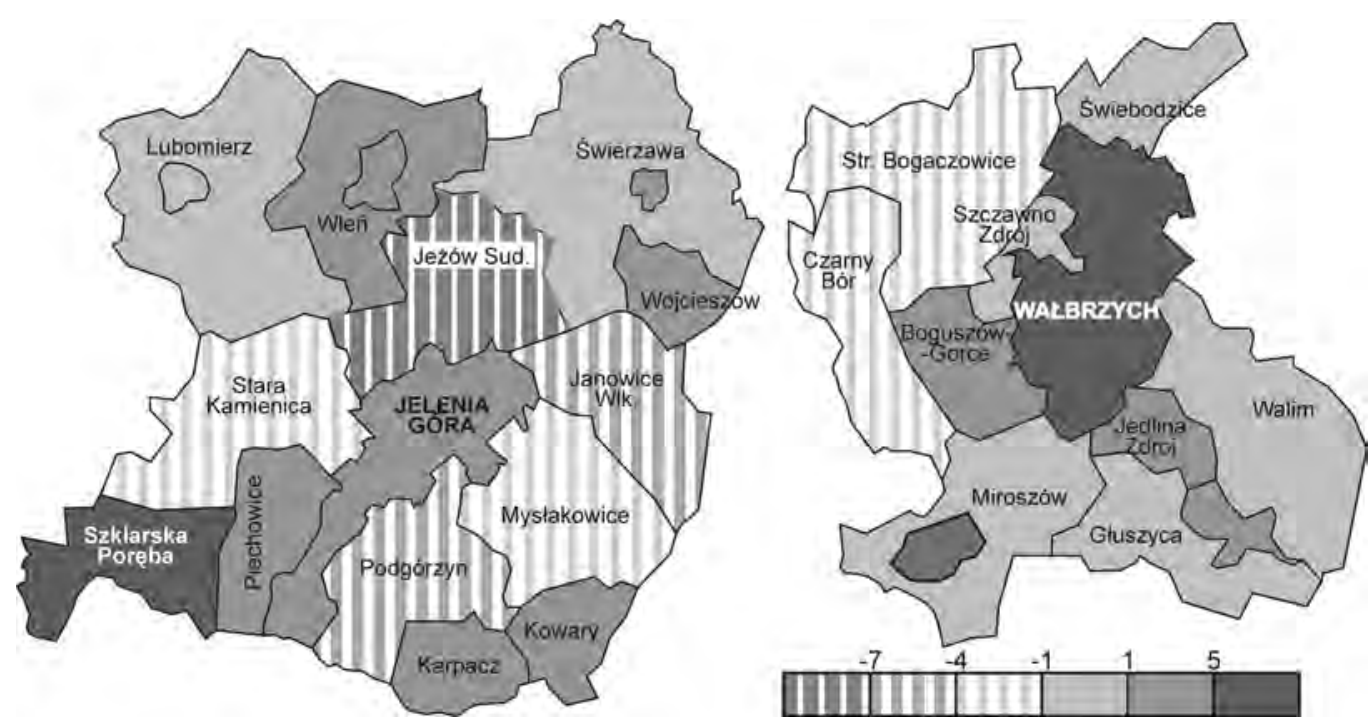

Rys. 7. Zmiany liczby ludności w gminach aglomeracji jeleniogórskiej i wałbrzyskiej w latach 1995-2014
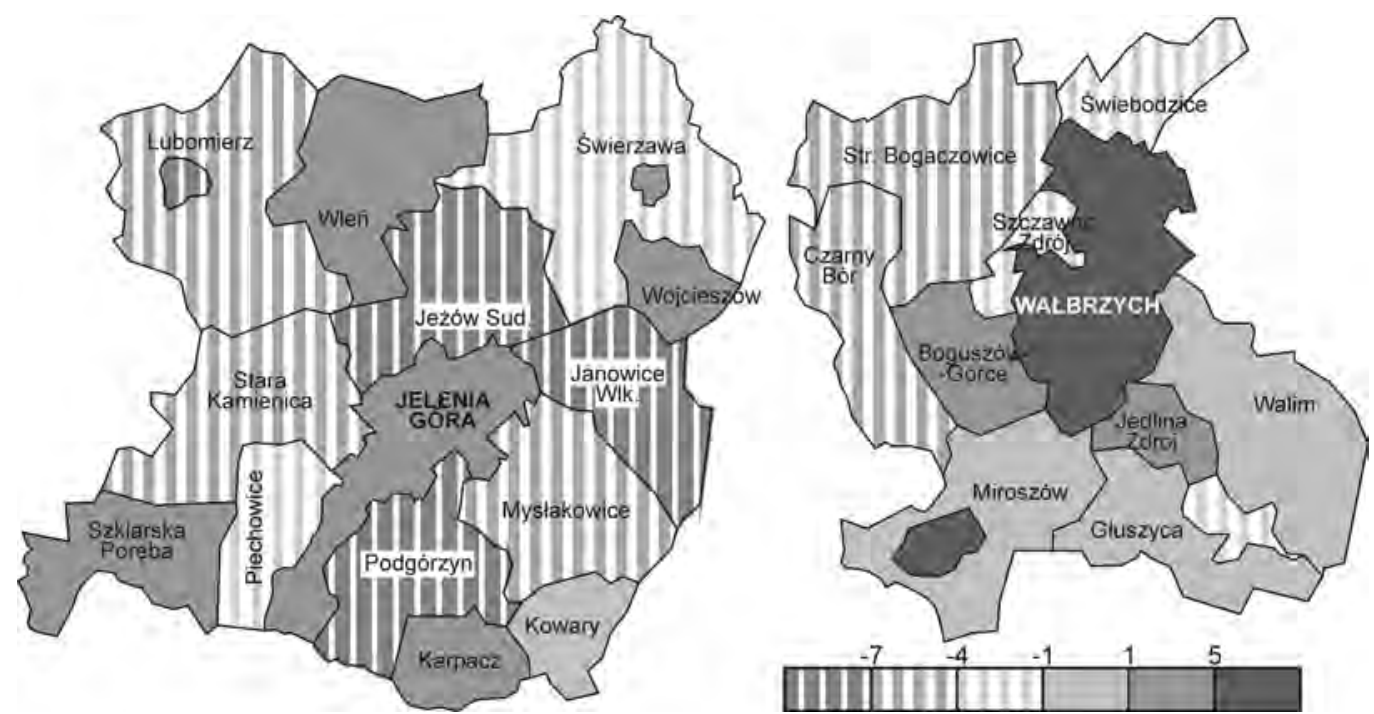

Rys. 8. Zmiany liczby ludności w gminach aglomeracji jeleniogórskiej i wałbrzyskiej w latach 2002-2014

Kształtowanie się stref podmiejskich wokół Jeleniej Góry i Wałbrzycha jest jeszcze lepiej widoczne przy analizie zmian liczby ludności w latach 2002-2014. W przypadku Jeleniej Góry strefa podmiejska obejmuje gminy: Jeżów Sudecki, Janowice Wielkie, Mysłakowice, Podgórzyn, Stara Kamienica i Lubomierz (rys. 8). Strefa podmiejska wokół Wałbrzycha jest z kolei znacznie mniejsza i obejmuje jedynie dwie gminy: Stare Bogaczowice i Czarny Bór (rys. 8). Świadczy to o zróżnicowanym tempie procesów suburbanizacji w aglomeracji jeleniogórskiej i wałbrzyskiej. Wynika to z dwóch głównych czynników. Pierwszym z nich jest odległość od Wrocławia (położonego $60 \mathrm{~km}$ od
Wałbrzycha i 110 km od Jeleniej Góry), która stanowi ważny kierunek odpływu mieszkańców obu zespołów miejskich. Nie bez znaczenia jest też lokalna konkurencja Wałbrzycha i Świdnicy. Drugim jest negatywny wizerunek regionu wałbrzyskiego, powszechnie uważanego za region poprzemysłowy, zdegradowany, o niskiej jakości środowiska (w 2011 r. w mieście został nawet powołany ruch Przejrzysty Wałbrzych, którego celem była poprawa wizerunku miasta), podczas gdy Jelenia Góra jest postrzegana jako „stolica Karkonoszy”, które są jednym $\mathrm{z}$ najważniejszych regionów turystycznych w Polsce. Te dwa czynniki kształtują odmienne zachowania przestrzenne ludności w obu zes- 
połach miejskich, przyczyniając się do odpływu mieszkańców z aglomeracji wałbrzyskiej oraz ich napływu do tworzącej się strefy podmiejskiej Jeleniej Góry.

Odmienność procesów demograficznych w obu aglomeracjach dobrze wyraża też ruch budowlany na ich terenie: znacznie bardziej nasilony $\mathrm{w}$ aglomeracji jeleniogórskiej niż wałbrzyskiej. W latach 1995-2013 w gminach aglomeracji jeleniogórskiej do użytkowania oddano 8331 mieszkań, podczas gdy w aglomeracji wałbrzyskiej tylko 3559. Największe natężenie ruchu budowlanego w tym okresie miało jednak miejsce w ośrodkach turystycznych: Karpaczu (91,4 mieszkania na 1000 mieszkańców), Szklarskiej Porębie $(81,5)$ i Szczawnie-Zdroju $(48,6)$, gdzie znaczna część nowych mieszkań przeznaczona jest na wynajem dla turystów lub jako tzw. drugie domy. Z gmin podmiejskich największe natężenie ruchu budowlanego odnotowano w gminach sąsiadujących z Jelenią Górą (rys. 9), jak np. Jeżów Sudecki $(79,8)$, Podgórzyn $(70,4)$ i Mysłakowice $(52,4)$, a w otoczeniu Wałbrzycha - w mieście Świebodzice (36,7) i gminie Czarny Bór $(33,8)$ (rys. 9).
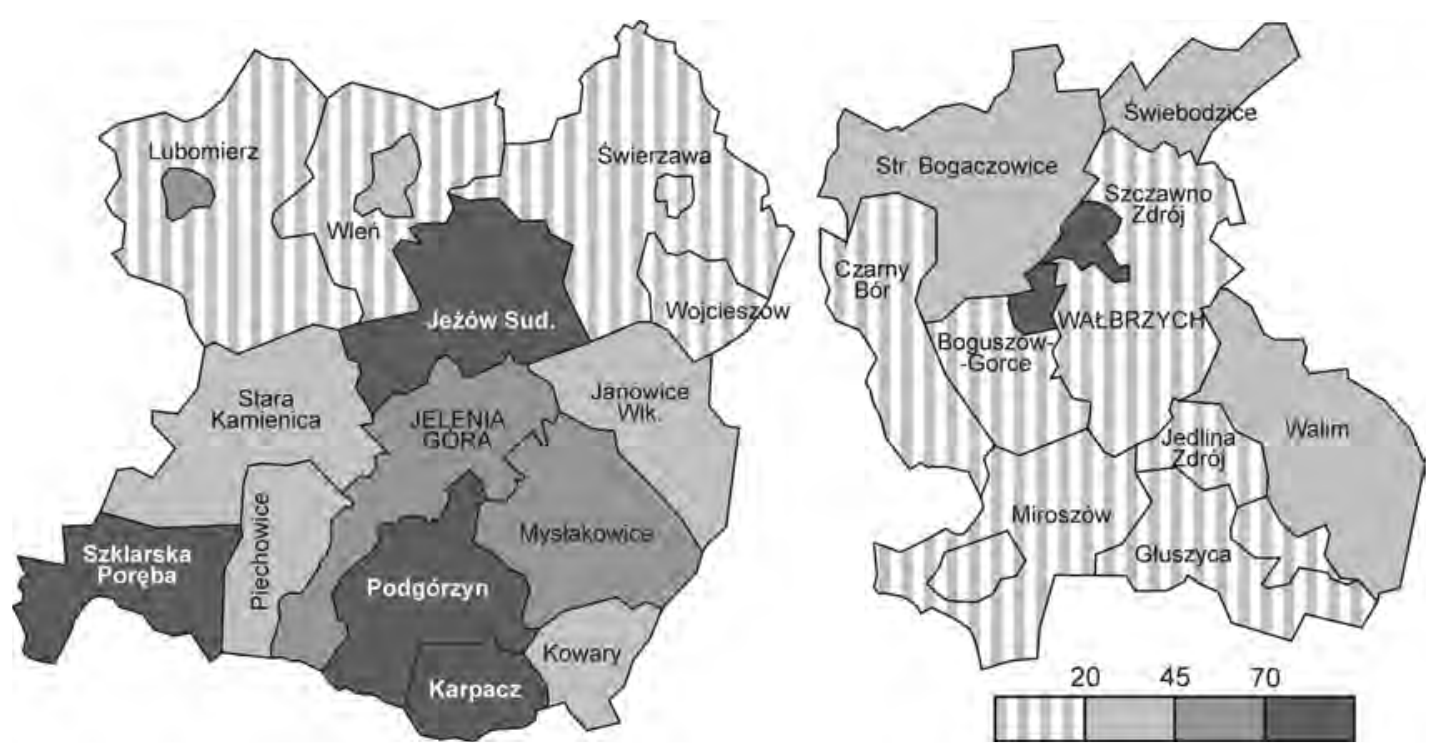

Rys. 9. Mieszkania oddane do użytkowania na 1000 mieszkańców w gminach aglomeracji jeleniogórskiej i wałbrzyskiej w latach 1995-2014
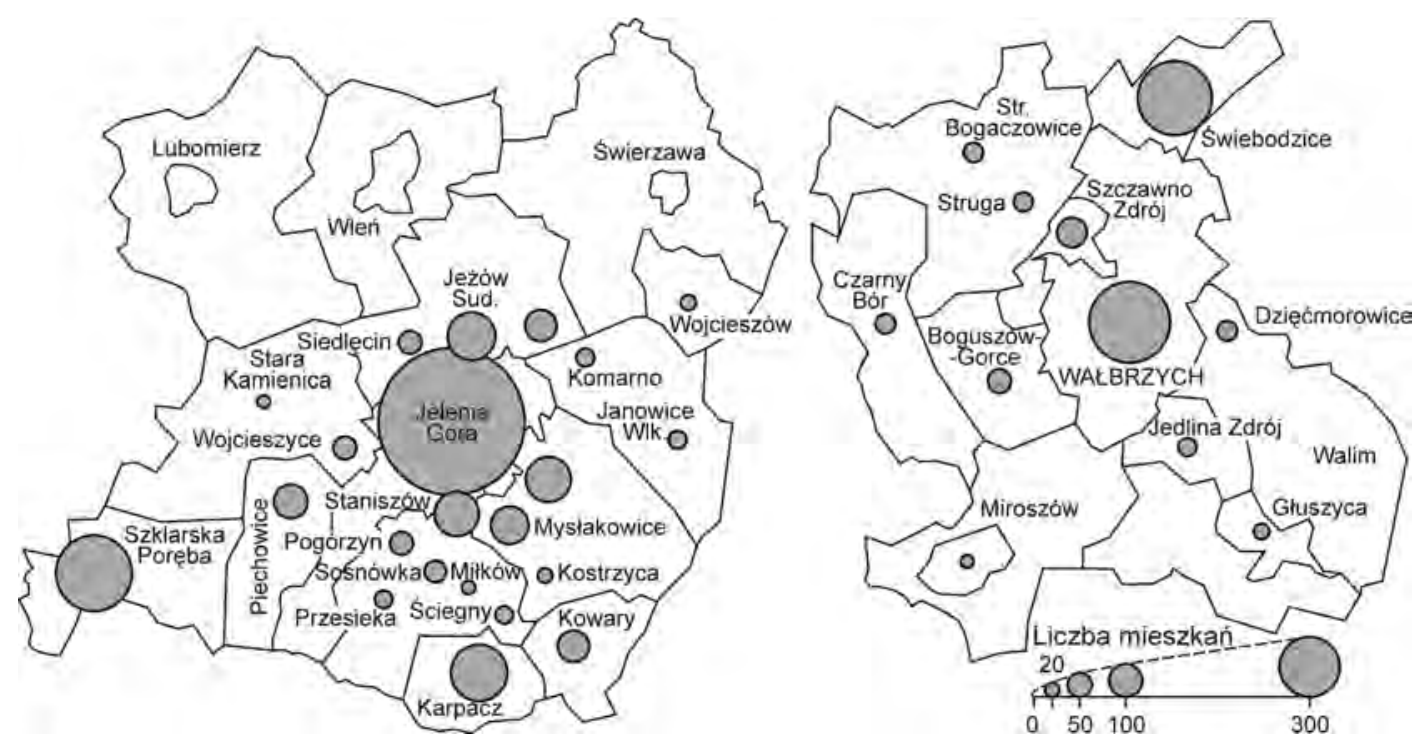

Rys. 10. Mieszkania oddane do użytkowania w miejscowościach statystycznych aglomeracji jeleniogórskiej i wałbrzyskiej w latach 2008-2014 
Analiza liczby mieszkań oddanych do użytkowania $\mathrm{w}$ poszczególnych miejscowościach statystycznych wykazała z kolei, że ruch budowlany na terenie obu zespołów miejskich skupiał się tylko w niektórych z nich. Można zatem stwierdzić, że procesy suburbanizacji w obu aglomeracjach w rzeczywistości obejmują tylko pojedyncze wsie, co świadczy o ich lokalnym zasięgu. W aglomeracji jeleniogórskiej były to wsie sąsiadujące z Jelenią Górą (rys. 10): Dziwiszów, Jeżów Sudecki i Siedlęcin w gminie Jeżów Sudecki, Łomnica i Mysłakowice w gminie Mysłakowice, Podgórzyn, Sosnówka i Staniszów w gminie Podgórzyn oraz Wojcieszyce w gminie Stara Kamienica, natomiast w aglomeracji wałbrzyskiej (rys. 10): Czarny Bór w gminie Czarny Bór, Stare Bogaczowice i Struga w gminie Stare Bogaczowice oraz Dziećmorowice w gminie Walim.

\section{PROGNOZA DEMOGRAFICZNA DLA AGLOMERACJI JELENIOGÓRSKIEJ I WAŁBRZYSKIEJ DO 2020 ROKU}

„Prognoza demograficzna dla gmin województwa dolnośląskiego do 2035 roku”, przeprowadzona na zlecenie Instytutu Rozwoju Terytorialnego we Wrocławiu (Górecka, Szmytkie 2015), w przypadku obu analizowanych zespołów miejskich wykazała utrzymanie się dominujących trendów demograficznych $\mathrm{w}$ najbliższych latach (rys. 11). W aglomeracji jeleniogórskiej do 2020 r. liczba ludności ma wzrosnąć w gminach: Jeżów Sudecki (o 10,0\%), Podgórzyn (o 1,8\%), Janowice Wielkie (o 1,4\%), Mysłakowice o (0,8\%), Stara Kamienica (o $0,3 \%$ ) i Wojcieszów (o 0,3\%), natomiast w pozostałych gminach wystąpi spadek liczby mieszkańców - największy w Szklarskiej Porębie (o 5,9\%), Jeleniej

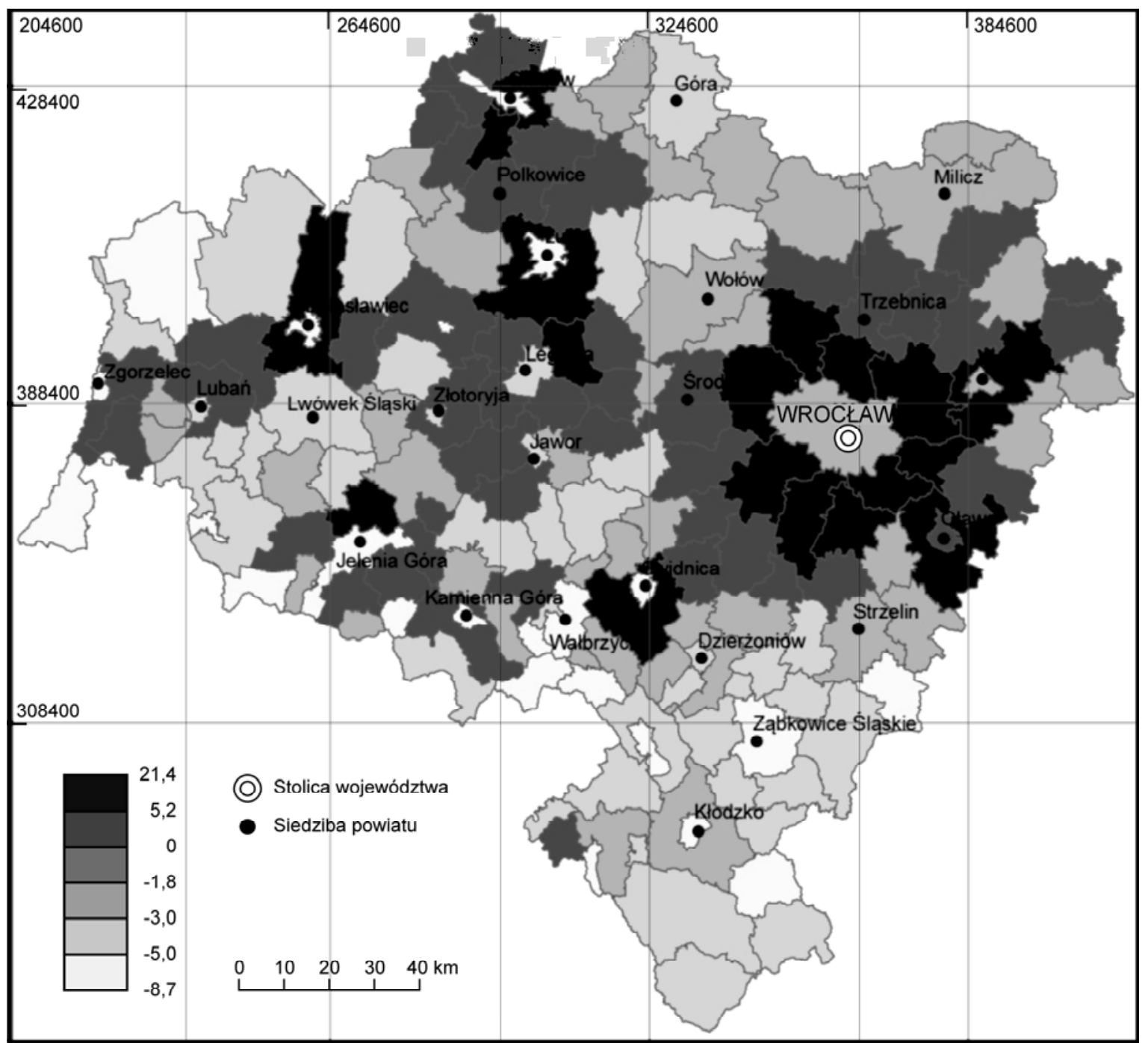

Rys. 11. Prognoza zmian liczby ludności w gminach województwa dolnośląskiego w latach 2013-2020 Źródło: zasoby Instytutu Rozwoju Terytorialnego we Wrocławiu 
Górze (o 5,5\%) i Kowarach (o 5,1\%). W całej aglomeracji jeleniogórskiej do 2020 r. liczba ludności zmniejszy się do 134,1 tys. osób, czyli o 3,1\% względem roku 2013. Znacznie gorsza sytuacja spodziewana jest w aglomeracji wałbrzyskiej, której liczba ludności spadnie do poziomu 188,7 tys. osób w 2020 r., czyli o 5,1\%. Ponadto we wszystkich gminach aglomeracji (z wyjątkiem gminy Stare Bogaczowice, gdzie prognozowany jest wzrost liczby mieszkańców o $0,8 \%$ ) wystąpi ubytek liczby ludności, a największy będzie w gminach Mieroszów (o 7,8\%) i Głuszyca (o 7,0\%) oraz w samym Wałbrzychu (o 6,3\%).

\section{PODSUMOWANIE}

Na sytuację demograficzną Jeleniej Góry i Wałbrzycha wpłynęły niekorzystne zmiany społeczno-gospodarcze i administracyjne w latach 90. XX w. (upadek górnictwa węglowego w Zagłębiu Wałbrzyskim, przebudowa bazy ekonomicznej związana z zamknięciem głównych zakładów przemysłowych, utrata statusu miast wojewódzkich). W obu miastach spadek zaludnienia nie jest rekompensowany przez procesy suburbanizacji w ich sąsiedztwie. Dotyczy to w szczególności aglomeracji wałbrzyskiej, gdzie suburbanizacji nie sprzyja słabość bazy ekonomicznej tutejszych ośrodków miejskich (z których stabilną i zróżnicowaną bazą ekonomiczną cechuje się tylko Wałbrzych) oraz niekorzystny wizerunek Wałbrzycha i całego regionu wałbrzyskiego jako zdegradowanego obszaru poprzemysłowego. Negatywny wpływ na sytuację demograficzną obu zespołów miejskich ma także oddziaływanie Wrocławia, który stanowi jeden z ważniejszych kierunków odpływu ludności z ich terenu. Dotyczy to w szczególności ludzi młodych, migrujących do stolicy województwa z przyczyn ekonomicznych lub edukacyjnych (Wrocław jest największym rynkiem pracy i ośrodkiem uniwersyteckim $\mathrm{w}$ południowo-zachodniej Polsce). Ten swoisty „drenaż” będzie prowadzić do dalszego pogłębienia się dysproporcji wewnątrzregionalnych oraz peryferyzacji południowej (sudeckiej) części województwa dolnośląskiego. Wydaje się bowiem, że gospodarka na tym obszarze, obecnie w znacznym stopniu oparta na turystyce, powinna być wzmocniona przez dywersyfikację działalności gospodarczej w głównych miastach.

\section{PRZYPISY}

${ }^{1}$ Dane pochodzą z Badania Aktywności Ekonomicznej Ludności przeprowadzone przez GUS.

2 Zjawisko to określane jest terminem względnej depopulacji (Kantor-Pietraga 2014).

\section{BIBLIOGRAFIA}

Cieślak M. (red.), 1999, Procesy demograficzne w byłych województwach dolnośląskich w latach 1945-1997, Wyd. Akademii Ekonomicznej we Wrocławiu, Wrocław.

Ciok S., 1995, Zmiany ludnościowe $i$ osadnicze w Sudetach, Prace Instytutu Geograficznego, ser. B, 12, „Acta Universitatis Wratislaviensis", 1730, s. 51-64.

Dołzbłasz S., Mucha P., 2015, Wykorzystanie terenów pogórniczych na przykładzie Wałbrzycha, „Studia Miejskie”, 17, s. 105-118.

Górecka S., Kozieł R., Tomczak P., 2009, Przemiany demograficzne na Dolnym Śląsku w latach 1999-2007, [w:] J. Łoboda (red.), Dolny Śląsk. Studia regionalne, Rozprawy Naukowe Instytutu Geografii i Rozwoju Regionalnego, 10, Uniwersytet Wrocławski, Wrocław, s. 23-39.

Górecka S., Szmytkie R., 2015, Prognoza demograficzna dla gmin województwa dolnośląskiego do 2035 roku, Instytut Rozwoju Terytorialnego we Wrocławiu, Wrocław.

Kantor-Pietraga I., 2014, Systematyka procesu depopulacji miast na obszarze Polski od XIX do XXI wieku, Wyd. Uniwersytetu Śląskiego, Katowice.

Koncepcja przestrzennego zagospodarowania kraju do 2030 (projekt), 2009, Ministerstwo Rozwoju Regionalnego, Warszawa.

Krzysztofik R., Szmytkie R., 2011, Studia nad procesami i strukturami osadniczymi sieci miast Polski Południowej, Prace Wydziału Nauk o Ziemi Uniwersytetu Śląskiego, 68, Uniwersytet Śląski, Sosnowiec.

Maciejuk M., 2015, Suburbanizacja miast średniej wielkości w Polsce na przykładzie Regionu Jeleniogórskiego w latach 19952013, „Studia Miejskie”, 20, s. 141-153.

Maleszka W., Szmytkie R., 2009, Zmiany ludnościowe w strefie podmiejskiej Wrocławia, [w:] W. Kamińska, M. Mularczyk (red.), Współczesne procesy urbanizacji obszarów wiejskich, Uniwersytet Humanistyczno-Przyrodniczy Jana Kochanowskiego w Kielcach, Kielce, s. 19-34.

Markowski T., Marszał T., 2006, Metropolie. Obszary Metropolitalne. Metropolizacja. Problemy i pojęcia podstawowe, KPZK PAN, Warszawa.

Mayer M., Szmytkie R., 2014, Kształtowanie się stref podmiejskich wokót miast średniej wielkości (studia przypadków z regionu południowo-zachodniego), [w:] A. Jezierska-Thöle, M. Biczkowski (red.), Zintegrowany rozwój obszarów wiejskich W świetle polityki Unii Europejskiej, t. 2: Wielofunkcyjność obszarów wiejskich, Wyd. Naukowe Uniwersytetu Mikołaja Kopernika, Torun, s. 121-152.

Miszewska B., 1989, Zmiany zaludnienia Sudetów w okresie powojennym, Czasopismo Geograficzne, 60(2), s. 135-145.

Smętkowski M., Jałowiecki B., Gorzelak G., 2009, Obszary metropolitalne w Polsce - diagnoza i rekomendacje, „Studia Regionalne i Lokalne", 1(35), s. 52-73; 
Spórna T., Kantor-Pietraga I., Krzysztofik R., 2015/2016, Trajectories of depopulation and urban shrinkage in the Katowice Conurbation, Poland (Les trajectories de déclin urbain dans l'agglomération de Katowice - Pologne), „Espace - Populations - Societés", 2015/3-2016/1, (Espaces en dépeuplement), DOI: eps.revues.org/6102.

Stryjakiewicz T. (red.), 2014, Kurczenie się miast w Europie Środkowo-Wschodniej, Bogucki Wyd. Naukowe, Poznań.

Szmytkie R., 2006, Sytuacja społeczno-ekonomiczna byłych miast wojewódzkich, [w:] J. Słodczyk, E. Szafranek (red.), Kierunki przekształceń struktury gospodarczej i społeczno-demograficznej miast, Uniwersytet Opolski, s. 99-110.

Szmytkie R., 2015a, Demograficzne i gospodarcze aspekty rozwoju miast Dolnego Śląska, Instytut Rozwoju Terytorialnego we Wrocławiu, Wrocław.

Szmytkie R., 2015b, Zjawisko kurczenia się miast bardzo małych w Polsce, [w:] A. Wolaniuk (red.), Współczesne czynniki i bariery rozwoju miast, XXVIII „Konwersatorium Wiedzy o Mieście”, Wyd. Uniwersytetu Łódzkiego, Łódź, s. 259-276.
Śleszyński P., 2013, Delimitacja Miejskich Obszarów Funkcjonalnych stolic województw, „Przegląd Geograficzny”, 85(2), s. 173-197.

Webb J.W., 1963, The natural and migrational components of population changes in England and Wales, 1921-1931, Economic Geography, 2, s. 130-148.

Wójcik J., 2011, Przemiany wybranych komponentów środowiska przyrodniczego rejonu wałbrzyskiego w latach 1975-2000, $w$ warunkach antropopresji, ze szczególnym uwzględnieniem wpływu przemyshu, Rozprawy Naukowe Instytutu Geografii i Rozwoju Regionalnego, 21, Uniwersytet Wrocławski, Wroclaw.

Zagożdżon A., 1990, Wybrane problemy ludnościowe Sudetów na tle rozwoju regionalnego, „Studia KPZK PAN”, 96, s. 95-111.

Artykuł wpłyną: 17 maja 2016

Zaakceptowano do druku:

21 września 2016 